\title{
Chapter 3 \\ The Asian Path of Economic Development: Intra-regional Trade, Industrialization and the Developmental State
}

\author{
Kaoru Sugihara
}

\begin{abstract}
This chapter discusses the Asian path of economic development from a long-term historical perspective. It is an attempt to understand the regionally specific context in which current emerging economies, especially India, Southeast Asia and China, industrialized. The basic demographic regime of monsoon Asia was formed in the early modern period, in which China and India developed a very large population-carrying capacity. The path of economic development was sustainabilitydriven, rather than growth-driven. In the nineteenth century and the first half of the twentieth century regional integration took place under the Western impact, which led to the growth of intra-regional trade and labour-intensive industrialization. A fully-fledged industrialization, with a rapid rise in living standards, followed in the second half of the twentieth century. In Japan the developmental state promoted national land development plans, and fostered capital- and resource-intensive industries in the seafront industrial complex along the Pacific coast. The development path of the countries in the Western Pacific rim at least partially became resourceintensive and growth-driven. In the most recent period, China extended this seafront model to a more comprehensive resource nexus model, which would enable the integration of the non-maritime parts of the country and the Eurasian continent into its growth orbit. This development requires a fuller mobilization of less tradable resources, such as water and ecosystem services, putting pressure on local resources and raising questions about environmental sustainability. The developmental state seeking both industrialization and environmental sustainability plays a crucial role in determining the future of Asia's development path.
\end{abstract}

\section{K. Sugihara $(\bowtie)$}

Research Institute for Humanity and Nature, Kyoto, Japan

e-mail: sugiharak83@gmail.com 


\subsection{Intra-Asian Trade as a Key Agent of Regional Industrialization}

This chapter discusses Asia's regional path of economic development, focussing on trade, industrialization and the developmental state. It is an attempt to understand the regionally specific context in which current emerging economies (especially India, Southeast Asia and China) industrialized from a long-term historical perspective.

In my previous work I suggested that the growth of intra-Asian trade was faster than that of world trade or Asia's trade with the West between 1880 and 1938 (Sugihara 1996, 2005: see Fig. 3.1 and Table 3.1). This was in sharp contrast to many parts of Africa, Middle East and Latin America where the local economies were integrated into the metropolis-led international economy as a satellite. Asian countries involved in this intra-regional trading network included a number of European colonies in South and Southeast Asia, as well as countries of East and Southeast Asia under unequal treaties and the treaty port system. They interacted with one another much more than other developing worlds did, through the growth of Indian, Chinese and other Asian merchant networks. It was these networks, together with the Japanese trade associations and government efforts to help them to compete with Asian networks (see Sugihara 1994), that facilitated the Japanese exports of labourintensive manufactured goods to other Asian countries. The growth of intra-Asian trade was instrumental to Japan's labour-intensive industrialization.

After a heavy intervention of the emergence, development and abrupt collapse of the Yen bloc in the 1930s and the first half of the 1940s, intra-Asian trade recovered
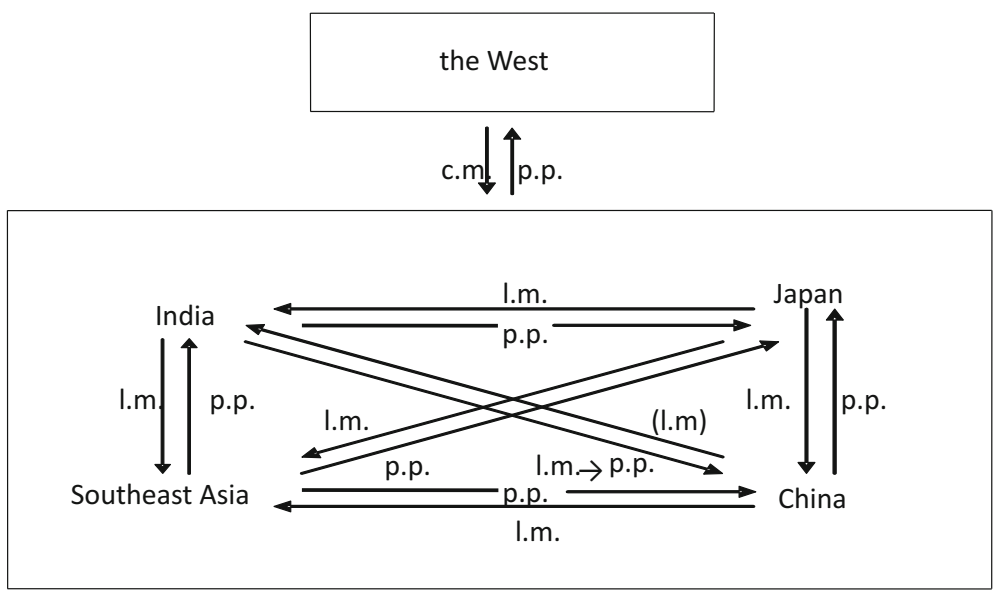

Fig. 3.1 Intra-Asian trade, c. 1880-1938 Source and notes c.m. capital-intensive manufactured goods, 1.m. labour-intensive manufactured goods, p.p. primary products. Since the late nineteenth century India exported cotton yarn to China in large quantities, but from the end of the 1910s, it was replaced by the exports of raw cotton. China exported a small amount of silk textiles in turn. Sugihara (1996): slightly revised 
3 The Asian Path of Economic Development: Intra-regional ...

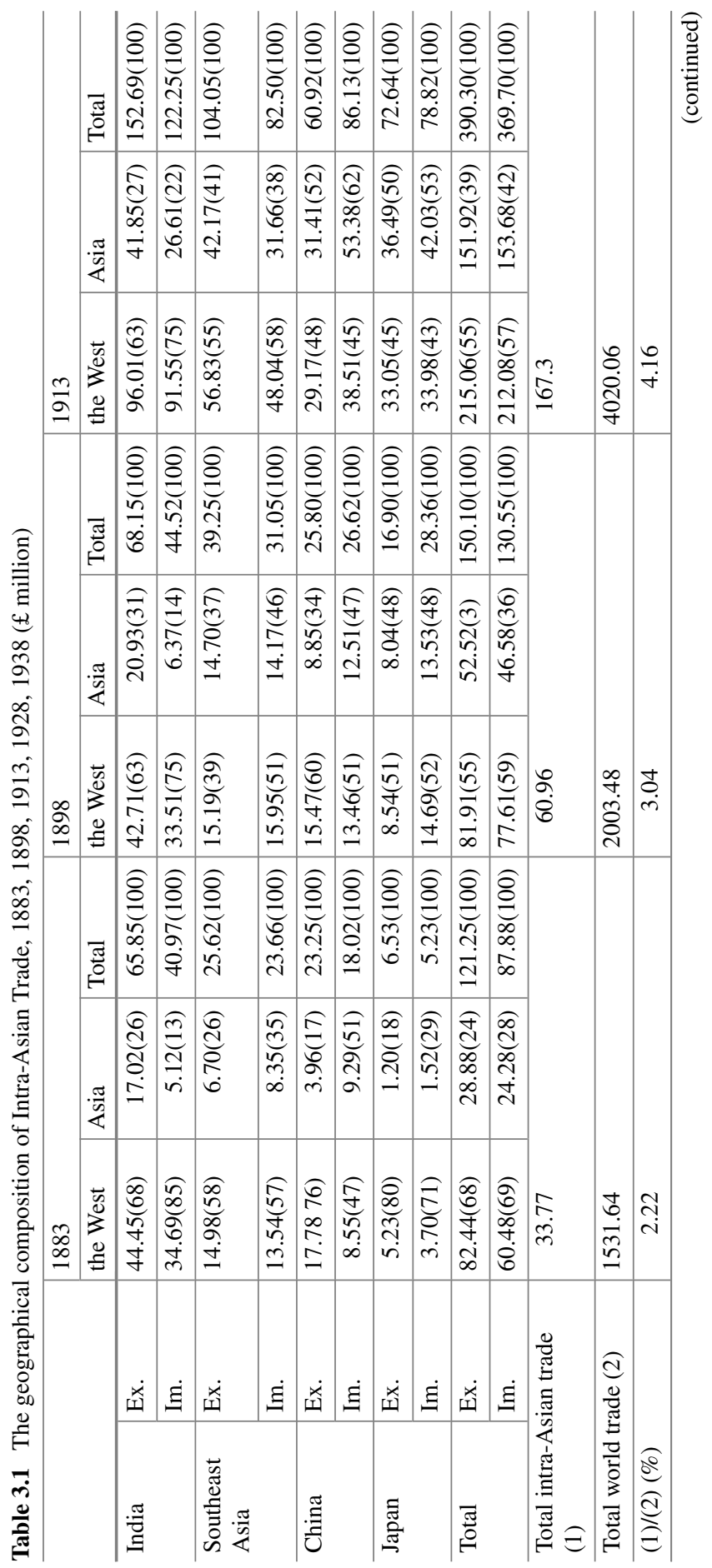




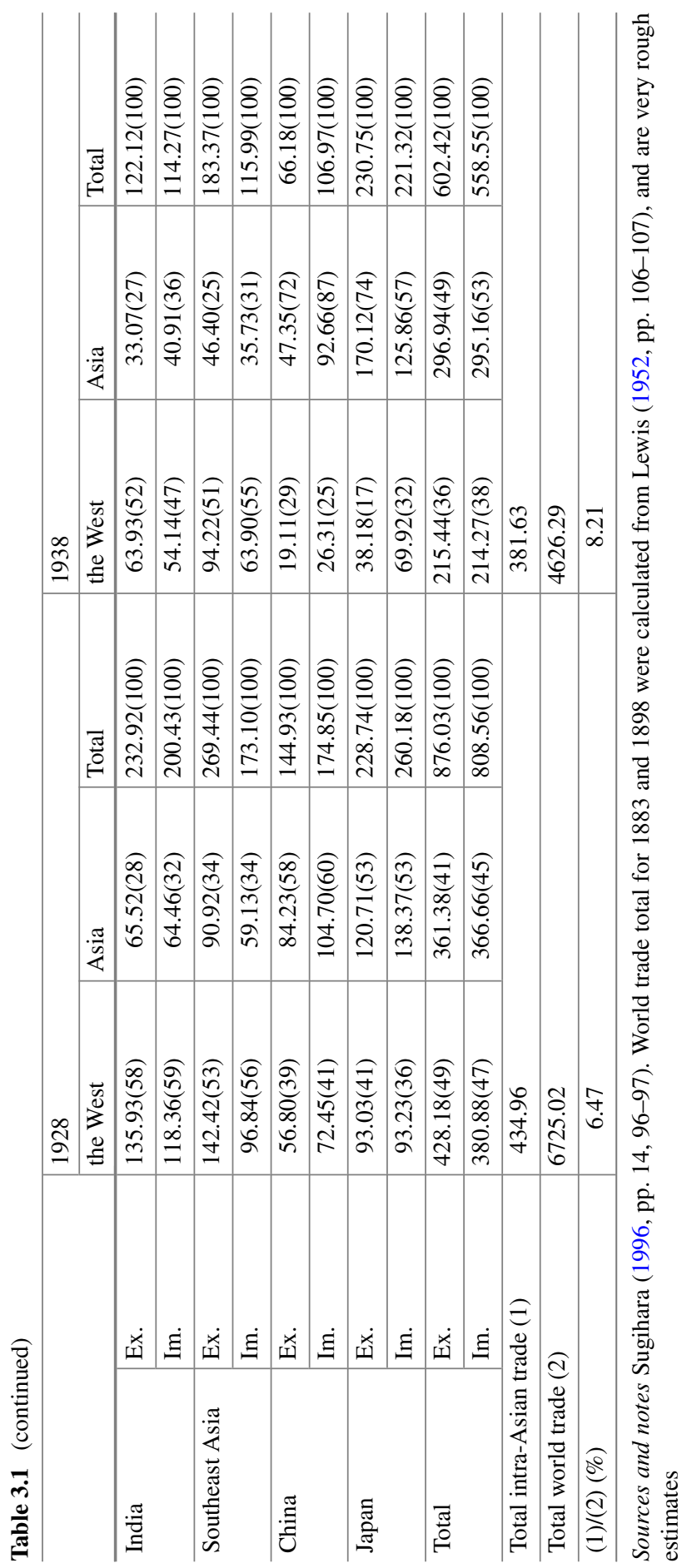


Table 3.2 Growth of Intra-Asian trade, 1950-2014 (billion dollars)

\begin{tabular}{|c|c|c|c|c|c|c|c|}
\hline \multirow[b]{2}{*}{1950} & \multicolumn{2}{|c|}{$\begin{array}{l}\text { (1) World exports } \\
\text { total }\end{array}$} & \multicolumn{2}{|c|}{ (2) Asia exports total } & \multicolumn{2}{|c|}{$\begin{array}{l}\text { (3) Intra-Asian trade } \\
\text { total }\end{array}$} & \multirow{2}{*}{\begin{tabular}{|l}
$\begin{array}{l}(3) /(2) \\
(\%)\end{array}$ \\
27.1 \\
\end{tabular}} \\
\hline & 58.0 & (100.0) & 10.7 & $(18.4)$ & 2.9 & $(5.0)$ & \\
\hline 1955 & 93.9 & $(100.0)$ & 13.4 & $(14.3)$ & 4.0 & (4.3) & 29.9 \\
\hline 1960 & 128.9 & $(100.0)$ & 18.3 & $(14.2)$ & 5.9 & (4.6) & 32.2 \\
\hline 1965 & 188.2 & $(100.0)$ & 25.7 & $(13.7)$ & 9.1 & (4.8) & 35.4 \\
\hline 1970 & 320.7 & $(100.0)$ & 44.4 & $(13.8)$ & 15.6 & (4.9) & 35.1 \\
\hline 1975 & 887.4 & $(100.0)$ & 143.4 & $(16.2)$ & 49.8 & (5.6) & 34.7 \\
\hline 1980 & 2018.1 & $(100.0)$ & 332.6 & $(16.5)$ & 135.9 & $(6.7)$ & 40.9 \\
\hline 1985 & 1987.0 & $(100.0)$ & 424.2 & $(21.3)$ & 167.7 & (8.4) & 39.5 \\
\hline 1990 & 3601.2 & $(100.0)$ & 805.4 & $(22.4)$ & 357.3 & $(9.9)$ & 44.4 \\
\hline 1995 & 5325.1 & $(100.0)$ & 1460.6 & $(27.4)$ & 764.8 & (14.4) & 52.4 \\
\hline 2000 & 6385.6 & $(100.0)$ & 1456.8 & $(22.8)$ & 738.9 & (11.6) & 50.7 \\
\hline 2005 & 10369.0 & $(100.0)$ & 2285.5 & $(22.0)$ & 1330.0 & $(12.8)$ & 58.2 \\
\hline 2010 & 14937.3 & (100.0) & 4495.3 & $(30.1)$ & 3073.9 & (20.6) & 68.4 \\
\hline 2014 & 18442.9 & (100.0) & 5603.2 & $(30.4)$ & 3905.9 & $(21.2)$ & 69.7 \\
\hline
\end{tabular}

Sources and notes Takanaka (2000). For figure from 2000 onwards, IMF, Direction of Trade Statistics Yearbook. The former work is based on UN commodity trade statistics, which is slightly wider in the scope of coverage than the IMF data, but the differences are small. Intra-Asian trade total refers to the value of exports from ten Asian countries (Japan, four NIEs, four ASEAN countries and China) and their imports from the smaller Asian countries (adjusted by FOB-CIF conversion)

fast among a much smaller number of countries in the post-war period. India, China and many Southeast Asian countries and North Korea withdrew from the regime of free trade, and a relatively small number of countries along the western Pacific coast (Japan, South Korea, Taiwan, Hong Kong and Malaya-Singapore among others) were integrated into the U.S.-led world economy. We then saw the high-speed growth of Japan, NIEs and ASEAN 4, followed by the reintegration of China, Southeast Asian countries (which joined ASEAN later) and India in the second half of the twentieth century, which led to a full recovery of the intra-Asian trading zone that existed in 1928. In the early post-war period the share of U.S. (and other Western countries) in Asia's trade was large, and its influence was dominant. However, the U.S. share rapidly declined, and was replaced by the growth of regionally-driven trade. In 2014 the share of intra-Asian trade in Asia's exports was as much as $70 \%$, a figure comparable to intra-E.U. trade (see Table 3.2). It has been by far the most dynamic section of world trade for the last half century.

Why has the growth of intra-regional trade been such a persistent tendency for the last hundred and thirty years? Our hypothesis is that there has been a dynamic relationship between the growth of intra-Asian trade and industrialization on a regional scale. That is, the growth of intra-Asian trade from the late nineteenth century helped Japan's labour-intensive industrialization, which in turn provided cheap manufac- 
tured goods such as cotton textiles and sundries to Asian peoples, and made the commodity composition of intra-Asian trade increasingly industrialization-driven. In the interwar period China went through import-substitution industrialization, which urged Japanese manufacturers to find more processed or higher-value added products for exports. Under the regime of 'selective' protectionism, Japanese manufacturers further increased the exports of textile machinery to China, which started regional industrialization. This was an original 'flying geese' (Akamatsu 1962), which has become a basic mechanism of progressively including higher value-added commodities and commodities made with the more advanced technology in intra-regional trade. The regional drive also targeted at opening up new markets for modern manufactured goods. Asian merchants and producers exploited the opportunity to identify local tastes and consumption patterns and to create a diverse range of demand for cotton cloth and sundries across Asia and beyond (think of exports of Indian and later Japanese cotton cloth to Southeast Asia and East Africa).

The post-war diffusion of industrialization, beginning in Japan and spreading to other Asian countries, has followed the same interactive path between intra-regional trade and industrialization, first among a small number of countries under the regime of free trade, and gradually embracing others [think of Asian textile complex in the 1980s in which Japan produced rayon [yarn], Taiwan wove it, and Hong Kong made it an apparel and exported it to the United States. See Arpan (1984: 112-117, 136-149, 159)]. Again, we do not see such a dynamic relationship in Africa, Middle East or Latin America in this period. South Africa and Brazil proceeded with industrialization without accompanying regional integration. It is only in Asia that economic nationalism has embraced regional integration on a regional scale. This trend continues to this day, most recently in the shape of the ASEAN Economic Community, and in spite of the emergence of China as a hegemon. By now labour-intensive industries reached many low-income countries (Sugihara 2013b).

This chapter is concerned with how such a distinctive feature has emerged. The key concept is intra-regional trade, as distinct from both local and long-distance trade. It created a regional division of labour between a commercial agricultural region and a proto-industrial region, and embraced industrialization by broadening the commodity composition of their trade. Its main career has been merchant networks, rather than the modern organization with the head office and a visible (Chandlerenian organizational) organizational structure, and both types remain important as careers of trade to this day. Intra-regional trade did not involve state monopolies such as European East India Companies, a product of mercantilism, but went hand in hand with the government policy of promoting trade and industrialization. In Southeast Asia, merchant networks were often responsible for the state formation in port cities and their hinterlands, which in turn provided institutional foundations of these networks. Where the power of the state was weak, merchant networks themselves organized schools, hospitals and social functions, to facilitate personal networks and information flows. Today they exist in the forms of overseas Chinese business associations, for example.

Implicit in these statements is that adopting a single country-based framework (e.g. Japanese history, Indonesian history) and considering intra-regional trade as a minor 
modification of such a framework are insufficient for the understanding of the context in which "emerging economies" reached the current level of development. What needs to be explained is how Asia as a region acquired global economic significance.

In the next section, I describe the pre-industrial roots of intra-regional trade and its relationships with the state, which governed the mobilization of resources. I argue that basic demographic profiles of these countries have been formed during the early modern period, and that China and India respectively developed a path, which was able to hold a very large population. It was a sustainability-driven, rather than growthdriven, path. In the nineteenth century and the first half of the twentieth century regional integration took place under the Western impact, which led to the growth of intra-regional trade and labour-intensive industrialization. Population growth became more regional, with a modest rise in living standards, especially in the maritime parts of Asia.

A fully-fledged industrialization, with a rapid rise in living standards, followed in the second half of the twentieth century. In the third section I discuss the post-war dynamics of intra-Asian trade and industrialization, focussing on the mobilization of labour and capital. Labour-intensive industrialization entailed the improvement of the quality of labour and livelihood, expressed in the Human Development Index, while capital- and resource-intensive industrialization was accompanied by the improved access to global resources. In Japan the developmental state promoted national land development plans, and fostered capital- and resource-intensive industries in the seafront industrial complex along the Pacific coast. The development path of the countries in the Western Pacific rim at least partially became resource-intensive and growth-driven. In the most recent period, China extended this seafront model to a more comprehensive resource nexus model, which would enable the integration of the non-maritime parts of the country and the Eurasian continent into its growth orbit. This development requires a fuller mobilization of less tradable resources, such as water and ecosystem services, putting pressure on local resources and raising questions about environmental sustainability. In the fourth section I discuss the importance of local resource constraints for the developmental state seeking both industrialization and environmental sustainability. The final section summarizes the main points of this chapter.

\subsection{Pre-industrial Roots and Trade Integration: the Western Impact}

\subsubsection{State Formation in Agrarian and Maritime Asia}

In understanding political and institutional foundations of Asia, it is important to go back to the evolution of state formation in the early modern period. The economic base of the state formation can be classified into three types: maritime, agrarian and nomadic. In both Mughal India and Qing China the nomadic empire came to rule 
a vast agrarian society, and transformed itself into the agrarian empire to a large extent. Judging by population size, these two agrarian empires were much larger than nomadic empires (the Ottoman empire was both nomadic and agrarian, but its population was smaller than the other two) and other earlier ones spanning vast regions of Eurasia. Within the environmental framework of monsoon Asia agrarian empires and their offshoots, including Japan, played a central role in the growth of population and the idea of welfare provision to sustain it. It was the agrarian empire that developed a regime of livelihood and resource security for ordinary people.

Various types of empires, states and other regional and international bodies tried to secure resources for their own survival and expansion. Among the most important means deployed were fiscal policy (typically tax extraction) and trade and territorial expansion. While in early modern Europe the execution of war was closely related to the issue of bonds and shares in the capital market, this was not the case in Asia. Land tax, together with monopoly sales, tariff, toll tax etc., served for the needs of the war, law and order, and the consumption of the ruling class. The Mughal Empire and the Tokugawa shogunate were perhaps the two states that extracted the highest proportion of agricultural output in the seventeenth century.

What made it possible for them to extract such a heavy tax for a long time? The main source was agricultural surplus. The source of surplus came from the high land productivity of rice agriculture in monsoon Asia where plenty of water and rich land were available, and labour-intensive technology and labour-absorbing institutions were developed. The 'industrious revolution' occurred both in Western Europe and East Asia, but it was in the latter that labour absorption led to population growth (Sugihara and Wong 2015).

The population-sustaining capacity was supported by the local community, as well as by an agrarian empire or state. In many peasant societies, including relatively land-scarce ones, village autonomy was guaranteed to a certain extent, as long as the village paid land tax and fulfilled other obligations. This was another way of providing livelihood and resource security. Within the local community welfare was provided by the family, the village community, market mechanisms and local hierarchies. In this case, the shape of centralized power differed region by region, in terms of the size of revenue, the extent of currency manipulation (by debasement and issuance of paper money), external policy, and the degree of freedom of migration. There was also diversity in the relationships between central and local governments. In the history of commons and common pool resources, institutions to deal with communal land emerged relatively early in land-scarce regions such as Japan and South India, while response to deforestation or decline of fish stocks came much later in resource-rich regions of Southeast Asia (Yanagisawa 2015).

Livelihood and resource security concerns in this period included not just the acquisition of food, shelter and clothing, but the more specific capacity to secure food during famine or food shortages and response to infectious diseases, disasters and war. While strong states were capable of destroying the livelihood of their people by conducting war or suppressing resistance, early modern states were also interested in the welfare of the people who were the foundation of their power. In seventeenth to eighteenth-century China, granaries stored food in preparation of local food short- 
ages (Will and Wong 1991). The main social mechanism of resource allocation and livelihood security in India was the caste system, which combined occupational division with status hierarchy. In certain castes, work/income rights (shares) were recognized and exchanged, while water, as well as land, was used to signal and reinforce social organization and hierarchy. The Mughal Empire built sophisticated architecture (including provision of water and construction of deep wells), cities and a network of roads by bringing in artistic, scientific and technical knowledge from the Islamic and Western worlds. Some of the knowledge and infrastructure had (largely unintended) external effects on sustaining the agrarian population.

Meanwhile, maritime states based on port cities and surrounding rural areas grew along the coasts of the Indian Ocean, including maritime Southeast Asia. Here the key organizing agents were port cities (or port city states) and networks of merchants (Reid 1993, 62-131). Products derived from sea, land and forest were all involved in the exchange economy. Helped by the presence of Indian and Chinese merchants, the region emerged as a trading world in which long-distance trade, regional trade and local trade actively interacted. Nevertheless, states did not develop a capacity to hold a large population. Resources were freely transferred through trade. The states thrived when they consolidated power or were in touch with other regions, including Asian agrarian and European overseas empires. If the state was relatively urban or commercially oriented, it could shift its fiscal base from one commodity to another, or from one economic activity to another, relatively easily. This flexibility was one important strength for securing resources and livelihood. The first serious economic contacts with Europe often began via these states. But their livelihood security was often threatened by external shocks through the introduction of infectious diseases, loss of comparative advantage as a result of the emergence of new production methods and trade regimes, and violence and war, in addition to natural disturbances, especially famines.

In peninsular Southeast Asia three military-fiscal states coexisted and competed with each other with a tendency for territorial consolidation in a way similar to European polity (Lieberman 2003). Even here commerce was important. Agrarian population was not necessarily the mainstay (for the Ayutthaya, see Baker and Phongpaichit 2017). Meanwhile, in the mountainous areas spanning South and Southeast Asia and China, people formed small political entities and retained their linguistic and cultural identities (Scott 2009). Furthermore, the impact of Islam (and Arab merchants) on the state formation in Indian Ocean trade regions cannot be ignored. All these features coexisted with agrarian empires and maritime states in South, Southeast and East Asia, often competing, overlapping or complementing with them.

It is possible to see a tendency for the two types of political units, agrarian and maritime, to initiate or encourage the growth of the market along each path. For example, the Chinese empire discouraged maritime expansion to a certain extent, but left the development of local and regional markets without heavy intervention. In eighteenth-century Jiangnan, where labour-intensive rice farming had developed, a significant proportion of cotton cloth was exported from the region; In addition, water buffalos had to be imported, and manure was brought from the North, to raise agricultural productivity (Li 1998, Chaps. 3, 4 and 6). The Tokugawa government 
was much more regulatory. It promoted the growth of the central market of rice through the collection of land tax, managed foreign trade under strict control, partly discouraged other types of trade, and regulated the growth of factor markets (in land, labour and capital). It was nevertheless 'market-enhancing', in that the system allowed relative socio-political autonomy, and even encouraged the peasant household to engage in commercial agriculture and proto-industry, especially from the latter half of the eighteenth century. Finally, the East Asian maritime networks were governed by the tendency to regulate long-distance trade, which denied the European style of expansion backed by military and technological capabilities. But by the end of the seventeenth century, pirate activities were curtailed, and East Asian seas became peaceful. In addition to, and partly in replacement of, the tributary trade relations, China developed a more equal regime of managed trade (the Hushi system), and both Japanese and Chinese governments recognized the utility of bilateral trade relationships, communicated through 'silent diplomacy' (Iwai 2010, 2012; Hao 2015).

By contrast, Indian Ocean trade was fostered by multi-layered networks of merchants, characterized by openness, spanning ecologically diverse areas, and with relatively large long-distance trade components. Territorial boundaries were observed, but the rules of exchange were not as imposing as in Europe, especially in sea. Europeans, Arab traders and local merchants overlapped in their operations, and they were not necessarily structured in a hierarchical way. The Mughal Empire was a strong fiscal military state, at least at its peak, but was relatively flexible towards trade, including maritime trade. In the Indian Ocean commodities from all over the world were exchanged as a result. Composition of commodities traded in the Atlantic or East Asia was not as comprehensive as that of the Indian Ocean (Chaudhuri 1990; Riello and Roy 2009).

\subsubsection{The Emergence of an Asian International Division of Labour}

In 1820, China's share in Asia's GDP was 59\% and South Asia 29\%, while Japan, South Korea, Taiwan and Hong Kong (using later territorial categories for the sake of comparison) took up 7\% and Southeast Asia 5\% (Asia's GDP was calculated as the sum of GDP of four sub-regions). By 1950, China' share declined to $28 \%$, while that of Japan and others rose to $21 \%$, Southeast Asia to $17 \%$ and South Asia to $33 \%$. Thus the four sub-regions became much more equal in terms of economic weight, though not of the size of the population. Within China and India economic progress mainly came from the coastal regions. The gravity of Asia's GDP shifted from the two agrarian empires in China and India to maritime monsoon Asia.

The key to this transformation was locational advantage. Economies of maritime monsoon Asia absorbed Western technology and institutions on the one hand, and mobilized local and regional resources on the other, through the development of 
transport networks, trade and migration. Two paths emerged as a result. In Meiji Japan, and a little later in coastal China, commercial ports in or near major cities, such as Yokohama, Kobe and Shanghai, connected imported and local resources, to help modern cities and industries grow. It was important that the emerging area had both the will to industrialize (thus committed to import technology and build an infrastructure to absorb it) and the social capacity to mobilize local resources, natural and human (including the ability to import or recruit them from other places). At the same time, in India and Southeast Asia, commercial ports, built by Western colonial powers, also connected imported and local resources to develop economies centred on port cities, but driven by the exports of primary products. They included Bombay, Madras, Calcutta, Singapore, and Jakarta. Hong Kong acted as a colonial port serving both for China and Southeast Asia.

The two paths were inter-related, and were not necessarily geographically separate: In fact the first modern industry emerged in Bombay in the middle of the nineteenth century, and soon met competition from Japan. Both China and Japan exported tea and raw silk in large quantities to earn foreign exchange. Commercial ports in Korea and Taiwan were developed by Japanese colonial authorities, to connect their primary exports to Japan. But there was also a divergence within maritime parts of modern Asia. South and Southeast Asia tended towards the path of primary producer economies, while East Asia tended towards industrialization.

Japan's labour-intensive industrialization was dependent on this growth of maritime economies, as well as being a major driver of it. In the early stage Japan exported rice and coal, but soon became an importer of these commodities as well as raw cotton and sugar. She competed with India in the market of cotton yarn in central China during the 1890s. By the early twentieth century she imported raw cotton from India, rice and sugar from Southeast Asia, Korea and Taiwan, and soybeans and their products from Manchuria, and exported labour-intensive manufactured goods such as cotton yarn cotton cloth and sundries to other parts of Asia. The environmental implication of this division of labour was a mitigation of local resource constraints, which enabled Japan to expand her industrial base, especially cotton textile industry. In this respect the basic logic was similar to England's discovery of 'ghost acreage' in North America during the period of the industrial revolution (see Pomeranz 2000, 274-278).

In the interwar period China went through import-substitution industrialization, which urged Japanese manufacturers to find more processed or higher-value added products for exports. Under the regime of selective protectionism, Japanese manufacturers also increased the exports of textile machinery to China, which started regional industrialization. This was an original 'flying geese' (Akamatsu 1962), which has become a basic mechanism of progressively including higher value-added commodities and commodities made with the more advanced technology in intra-regional trade. Japan adopted a policy of selective protectionism, that is, setting up tariff barriers only against imports directly competing with the domestic industry attempting import-substitution but pursuing the benefit of free trade, as a result of which her overall tariff rate stayed relatively low, while China and India raised tariff rates, partly for revenue purposes but also to more comprehensively protect domestic industries. 
Japan's dependence for the imports of raw materials was much greater than that of the other two countries.

Countries involved in intra-Asian trade included a number of European colonies in South and Southeast Asia, as well as countries of East and Southeast Asia under unequal treaties and the treaty port system. Under this system of 'forced free trade', Japanese merchants brought a wide range of cotton manufacture (cloth and apparel) and sundries (matches, soap, toothpaste and tooth brushes, traditional medicine, umbrellas, bicycles and noodle-making machines) to Asian peoples, and they interacted with Indian, Chinese and other Asian merchant networks. It was these networks, together with the Japanese trade associations (and government efforts to help them to compete with Asian networks), that facilitated the exports of labour-intensive manufactured goods. With a time lag and a series of heavy political disturbances, labour-intensive industrialization spread to China and eventually to other parts of Asia.

In Southeast Asia the crucial moment came in the late nineteenth to the first half of the twentieth centuries when modern maritime (mostly colonial) states seriously began to interact with populous Asian states, which proceeded with industrialization. Under the Western impact, the fusion between the two created massive migration of Indian and Chinese labourers to Southeast Asia, the growth of intra-Asian trade between Southeast Asian primary producers and other Asian producers of manufactured goods, and above all the sense of sharing of modern consumption goods among the ordinary Asian peoples (from rice, dried fish, spices and a range of nontimber forest products to cotton cloth and sundries mentioned above). The traditional commodity complex shared in the region (rice, sugar, tea, silk and cotton) remained important, but a modern Asian international consumer culture emerged through intra-Asian trade and labour-intensive industrialization. This in turn made it easier to transfer labour-intensive technology and managerial know-how, and prepared for regionally-driven industrialization in the post-war period.

\subsection{The Post-war Industrialization and the Developmental State}

\subsubsection{Open Regionalism Under the Developmental State}

The government in the inter-state system, which attempts to maximize the interest of its people, could act against the principle of free trade, which seeks mutual gain. In post-war Asia, there was a greater sense of tension between the need for political and economic independence and intra-regional trade than pre-war. On the one hand, independence meant gaining a political and economic autonomy, especially in relation to the former colonial power, and more generally to advanced Western countries. At the same time, the pre-war path dependency suggested that there was room for newly independent countries to take advantage of regional commercial networks, 
especially through the entrepots of Hong Kong and Singapore. In this section, we discuss how the states reacted to the issue of economic integration through trade, and eventually most of them came to engage in intra-regional trade and competitive regional industrialization.

The strategy for the 'import substitution industrialization', strictly interpreted, meant the building of a full industrial structure equivalent to that in developed countries, by imposing very high tariff against imports of industrial goods from the West. This strategy seemed politically viable in many countries, including India and China, though it turned out to be relatively short-lived. In India, by the Third Five Year Plan period, it became clear that benefits of heavy industrialization (modelled largely on the Soviet experience) were not being 'trickled down', resulting in 'disguised unemployment' in the rural area and the growth of the urban 'informal sector'. In communist China (during the Mao period), human development indicators (such as education and health) improved faster than in the more democratic India, but the country also struggled to develop competitive heavy industries (also originally influenced by the Soviet experience) in the absence of technological transfer from the more developed countries, especially from the West.

By contrast, some East and Southeast Asian countries, such as Japan, NIEs (Newly Developing Economies of South Korea, Taiwan, Hong Kong and Singapore, which had relatively high initial conditions of various kinds) and ASEAN 4 (Thailand, Malaysia, Indonesia and the Philippines, which pursued the export-oriented path to industrialization) successively experienced relatively high rates of growth, by taking advantage of the gains from trade more than India and China.

South Korea and Taiwan were among the first that captured the concept of exportorientation in industrialization, partly because they were too small a country for developing a comprehensive industrial structure, and partly because they lacked the natural resources (especially mineral and energy) needed for economic growth in much the same way as Japan did. In both cases political autonomy was complicated as much by territorial relations (with North Korea and China) as by dependence on exports, while Japan's was conditioned by the defeat of the war. It was important that these countries nevertheless pursued a policy for export promotion and were able to link it to both resource imports and employment creation.

ASEAN 4 started a developmental policy under the authoritarian regime around 1965. They gradually turned to the export-oriented strategy, coined by Hla Myint in an ADB-sponsored conference in 1970, and proceeded with a full route to industrialization in the 1980s (This can be seen in the radical change in their commodity composition of trade). In spite of the criticism of 'shallowness' of industrialization (Singh 1979) and the lack of initial conditions (such as the land reform) taken for granted in East Asia (Lee 1979), they pursued the export-oriented industrialization strategy with varying degrees of success. It became a mainstay of growth Asia's economic policy. Neither the U.S., the key provider of political and military support, nor former colonial powers (European states and Japan), has been primarily responsible for the diffusion of this strategy. If anything, it grew out of what was happening on the ground, rather than as a result of economic principles or policy directives from above. Even so, it was vital for some ideas and policies to be articulated and pursued. 
The 'open regionalism', which does not discriminate against countries outside the region when regional integration takes place and tariff rates are reduced inside the region (that is, this strategy proposes to reduce tariff rates against outside one-sidedly), derives from a special type of economic nationalism, which is different from both the hegemonic regime of free trade (as per Britain and the U.S.A.) and Continental European style regime of free trade through treaty networks (Sugihara 2015). Historically, the region was used to low tariff level exposure to the international economy, especially in the late nineteenth and early twentieth centuries under the regime of 'forced free trade'. It was natural for these Asian countries to engage in trade between neighbouring countries with similar economic structure and to compete for similar markets, in order to seek complementarity for small gains from trade and exploit regional potentialities for growth. Trade was seen, not just as a policy tool for economic growth or industrialization, but as a prime mover in itself. India and China, which had been an agrarian empire in the early modern period and opted for strict import-substitution industrialization in the post-war period, were slow to join this regional dynamics. Nevertheless, their long-term trajectories were not necessarily of agrarian origin. Both countries had long traditions of engaging in regional trade.

After the policy changes in 1979 and in 1991, China and India joined the network of trade and economic growth, and in many ways led the dynamism. China retained a high rate of growth for more than three decades, only with minor downturns, and increasingly traded with other Asian countries. Although the impact of foreign investment in China (from U.S., E.U. and Japan as well as from overseas Chinese capital) was significant as a vehicle of technology transfer and the training of labour, the increased significance of intra-Asian trade cannot be accounted for by such investment flows alone. Along with the growth of production networks initiated by multinational companies spanning greater Asian regions, the amount of smaller, local and regional transactions between China and Southeast Asia and other neighbouring countries increased in parallel to them. As a result, Asia's share in Chinese trade continued to grow. It was China that sustained the growth of commercial linkages among Asian countries in the more recent years, in many ways replacing the role Japan (and NIEs) had played earlier.

By 2000 India was trading eastwards (mainly with growth Asia and the U.S.) more than westwards (mainly with E.U., Russia and the Middle East). In 2015 she became the fastest growing country among the main emerging states, rapidly becoming part of Asia's regional growth. It is clear by now that 'growth Asia' began to include the 'hinterland', as well as smaller countries of Asia. By making a vast rural population closer to trade-inspired industrialization, the policy changes in China and India had a major impact on the rise of emerging economies in particular and global economic development in general.

China today is trying to distance itself from the norms and institutions that have governed the original Asia-Pacific economy, which was created in the 1950s to the 1970s by the United States, Japan, ASEAN and Australia. They include U.S. hegemony in military and international relations, as well as rules of international trade and monetary systems. The crucial question, however, is whether these moves 
will affect the forces promoting intra-regional trade. So far China appears to want to use them, so long as they do not contradict with its political and territorial interests.

\subsubsection{Labour-Intensive Industrialization and the Improvements of the Quality of Labour}

In 1954 Arthur Lewis wrote "Economic Development with Unlimited Supplies of Labour", in which he characterized labour in developing countries as abundant, homogenous and disposable, and described Asian labour in the 1880s as a powerful force of international labour market "willing to go to the ends of the earth for a shilling a day" (Lewis 1954, 1978). This was a polarization story, in which highwage economies in the West and low-wage economies in the non-European world grew simultaneously without a 'convergence'.

Instead, post-war growth Asia saw a steady improvement of the quality of labour, best seen in the progress of education, but also obvious in the type of industries which developing Asia has successfully established, especially in industrial clusters with a range of machinery industries. In manufacturing industry growth Asia substantially 'caught up' with the West. The main explanation for labour-intensive industrialization rests on the comparative advantage of an industrializing economy, that is, if labour is abundant and capital (and land) are scarce but the economy has a social capacity to industrialize, it tends to develop a set of technology and institutions that use more labour and less capital. In practice, major differences between East Asia and Western Europe came from the degree and speed of urbanization, which is relatively capital-intensive. Differences also came from the type of industries: (relatively capital-intensive) machine spinning diffused faster in the West, while the survival and development of (relatively labour-intensive) hand-weaving industries was more visible in East Asia. But at root there was the question of availability of labour of a good quality. Labour-intensive industrialization needed competitive and adaptable labour, which enabled industries to grow into a technology-inducing and institution-developing mode.

How did Asia acquire such labour? Elsewhere I have argued that there was an 'industrious revolution' in East Asia in the early modern period. Labour-intensive technology and labour-absorbing institutions developed to increase land productivity, and enabled the peasant household to combine rice farming, commercial agriculture and proto-industry. General, managerial and inter-personal skills (as against specialized, technical and individual ones) were formed. In Japan (and later in China) industrial workforce did not come from the proletariat but came from the peasant household. Early workers of peasant origin (including many young girls) were largely illiterate, but many of them were disciplined to become a labour of a good quality after they were transferred to modern factory. In Meiji Japan the real wage was low compared to that in the West, and working conditions were often harsh. One factor 
that made Japanese labour-intensive industries competitive was the high quality of labour relative to the wage (Sugihara 2013b).

Not all countries had as high initial conditions as Japan. Beginning in Japanese mills in China and India from the end of the nineteenth century onwards, we hear frequent complaints of Japanese factory managers about the quality of non-Japanese labour, often with culturally biased languages. The more rigorous observations and studies found differences in the rates of absenteeism, the response to incentive schemes and the degree of commitment to work in different places and in different periods. Nevertheless, a general trend is clear: As industrialization proceeded, a much larger proportion of labour became educated and/or skilled, while cheap labour in harsh working conditions remain in developing countries. Income inequality increased, though not always sharply, as expected in the Kuznets curve. But the speed of development of manufacturing industries was so rapid that the average manufacturing wage went up.

We briefly record evidence of the regional dimension of industrial upgrading. Between 1972 and 1985 'new' high technology industries grew faster in Asia than in the U.S.A. and Western Europe, although the original technology (mainly computer and communication technology) substantially came from the United States (Table 3.3). The ILO studies in labour-intensive industries and human resource development extensively discussed the 'matching' between the nature of new demand for skills on the one hand, and education and formal training on the other (Amjad 1981, 1987). Not many attempts were successful, nor were they comprehensively pursued by the government, but by the 1980s the direction of thinking was clearly towards the development of human capital, or in manufacturing, workforce of a good quality. This was linked to the shift towards a more balanced allocation of educational expenditure between primary, secondary and tertiary sectors [Many developing countries in Asia overspent on tertiary education, while spending too little on primary education at the early stage of industrialization. See Lindert (2003, 2004)]. An overall result was a simultaneous rise of per capita GDP and the Human Development Index (Table 3.4).

This is now history, and we face the 'middle income trap' today. My first observation is that the dynamics of intra-Asian trade and technology and managerial transfers at the level of labour-intensive industries (therefore to some extent at the level of related tertiary industries) remain at work. In terms of trade-driven growth, Asia is one of the best hopes among the emerging economies, largely as a result of alternating growth spurts in Southeast Asia, China and India and a high degree of regional integration.

My second observation is that stagnation of developed countries can be a cause of trap or a source of growth. From 1931 to 1936 Japan grew faster than most Western countries, and proceeded with heavy industrialization. This partly came from the 'import-substitution industrialization', in the sense that a competitive pressure from the West was eased (largely as a result of the Great Depression and the devaluation of the yen) and many domestic machinery sectors developed. The intra-Yen bloc trade now included a significant proportion of machinery trade. But it was also a move towards a 'relative autonomy', echoing post-war India and China, in that 
Table 3.3 Trends of domestic demand in volume terms by branch of industry in the european community, the United States and Japan (average annual growth rate, 1972-85) (\%)

\begin{tabular}{l|r|r|r}
\hline & EC & U.S.A. & \multicolumn{1}{l}{ Japan } \\
\hline Strong-demand sectors & $\mathbf{5 . 0}$ & $\mathbf{5 . 2}$ & $\mathbf{1 4 . 3}$ \\
\hline Office machines, data-processing equipment & 9.0 & 6.5 & 7.2 \\
\hline Electrical and electronic equipment and supplies & 3.5 & 7.2 & 20.7 \\
\hline Chemicals and pharmaceuticals & 5.3 & 2.3 & 9.9 \\
\hline Moderate-demand sectors & $\mathbf{1 . 2}$ & $\mathbf{2 . 8}$ & $\mathbf{3 . 1}$ \\
\hline Rubber, plastics & 2.8 & 5.4 & 2.0 \\
\hline Transport equipment & 1.7 & 2.7 & 5.2 \\
\hline Foodstuffs, beverages, tobacco & 1.2 & 0.4 & 0.0 \\
\hline Paper, printing & 1.6 & 2.9 & 2.7 \\
\hline Industrial and agricultural machinery & -0.1 & 5.6 & 5.6 \\
\hline Weak-demand sectors & $\mathbf{- 0 . 3}$ & $\mathbf{0 . 5}$ & $\mathbf{2 . 4}$ \\
\hline Metal products & -0.5 & -0.4 & 3.4 \\
\hline Miscellaneous industrial products & -0.6 & 2.1 & 1.9 \\
\hline Ores and ferrous and non-ferrous metals & 0.6 & -1.8 & 2.0 \\
\hline Textiles, leather, clothing & -0.2 & 2.0 & 2.2 \\
\hline Non-metallic minerals (construction materials) & 0.1 & 1.7 & 1.1 \\
\hline
\end{tabular}

Sources and notes van Liemt $(1992,12)$. Data derive from Commission of the European Communities, International Trade of the European Community: A View of Certain Aspects of the External Trade of the Community, Directorate-General for Economic and Financial Affairs, European Economy, No. 39, Brussels 1989

Table 3.4 Human development index, 1960-1995

\begin{tabular}{l|l|l|l|l}
\hline & 1960 & 1970 & 1980 & 1995 \\
\hline U.S.A. & 0.865 & 0.881 & 0.905 & 0.943 \\
\hline Japan & 0.686 & 0.875 & 0.906 & 0.940 \\
\hline Hong Kong & 0.561 & 0.737 & 0.830 & 0.909 \\
\hline Singapore & 0.519 & 0.682 & 0.780 & 0.896 \\
\hline South Korea & 0.398 & 0.523 & 0.666 & 0.894 \\
\hline Thailand & 0.373 & 0.465 & 0.551 & 0.838 \\
\hline Malaysia & 0.330 & 0.471 & 0.687 & 0.834 \\
\hline Indonesia & 0.223 & 0.306 & 0.418 & 0.679 \\
\hline Philippines & 0.419 & 0.489 & 0.557 & 0.677 \\
\hline China & 0.248 & 0.372 & 0.475 & 0.650 \\
\hline India & 0.206 & 0.254 & 0.296 & 0.451 \\
\hline
\end{tabular}

Source UNDP, Human Development Report (1996) 
most new industries were linked to the research and development efforts relating to Japan's military industries and territorial expansion (Sawai 2012). If the direction of industrial development was driven by political and military interests (and in Japan's case without a full understanding of global military and resource balances), there was no guarantee, or even a prospect, that the country was adopting a sensible importsubstitution strategy based on factor-endowment considerations.

\subsubsection{Capital-and Resource-Intensive Industrialization and the Improvements of Physical Infrastructure}

To some extent rapid industrial upgrading in Japan along the lines of labour-intensive industrialization was complementary to the more capital- and resource-intensive industries, especially in the U.S. But it also resulted in the upgrading and expansion of capital- and resource-intensive industries within Asia. Imports of fossil fuels, including oil and liquefied natural gas (LNG), and other raw materials became essential for this purpose.

In the 1950s there was a debate over how Japan's resources should be secured, especially as to whether its energy demand should depend on domestic coal or on imported oil. High economic growth and rapidly rising demand favoured the latter option. There was also a coordinated attempt by Ministry of International Trade and Industry (MITI) to spread the energy-saving methods of production in steel and electrical machinery industries. In the second half of the 1950s serious attempts were made to develop a 'seafront industrial complex (rinkai kogyo chitai)' to serve for oil refinery, petrochemical industry and electricity generation industry among others (see Fig. 3.2). There was an accumulation of knowhow prior to this period, including the idea of establishing the 'industrial port' as distinct from the 'commercial port'. International circumstances also strongly favoured this strategy. A sudden expansion of oil production in the Middle East was not being met by the matching increase of demand in Europe, and majors were looking for their customers. This gave Japanese companies the opportunity to negotiate with Western firms on technology transfer on good terms (Kobori 2010).

Pursuit for the seafront complex involved a number of industrial and infrastructural developments. Against the background of low prices of resources and energy, Japanese shipbuilding companies and shipping lines attempted to utilize the latest technology of large oil tankers and other specialist bulk vessels (e.g. for iron ore) to the full. Equally important was a rapid introduction of container cargoes for other commodities, which standardized shipments across international ports, and helped coordinate the transfer of goods between different means of transport in industrial ports. The seafront complex was constructed with dredging and reclamation, centered on a deep habour which could take large vessels. Railway lines and roads were built to ensure access. The establishment of the industrial site required pursuit of the economies of scale on the one hand, and political and public approval on the other. In 


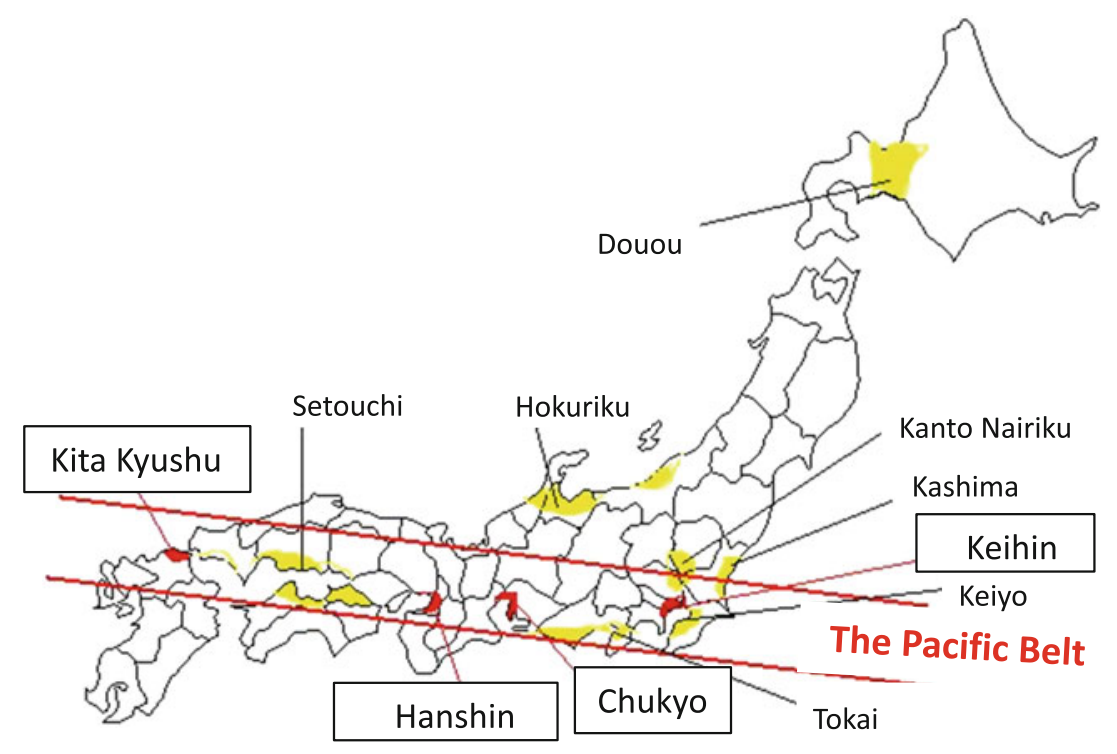

Fig. 3.2 The industrial belt in the Japanese Pacific Coast Source and note Adapted from http:// hiroseki.sakura.ne.jp/industry.html

the 1960s the Japanese political will was strong enough to push the 'Pacific industrial belt' development at a speed inconceivable in the established industrial districts in the West.

The industrial complex was typically located not in the central parts of major cities such as Tokyo and Osaka, but in neighbouring areas. For example, Tokyo retained employment-absorbing labour-intensive (by then mostly skill-intensive) industries within the central wards, while the bay areas of Yokohama became home to the resource-intensive cluster. After the second half of the 1960s environmental protection movements began to spread, and the municipal government absorbed the voice of the citizens before the central government did. Such politico-social dynamics partially resulted in the diffusion of the industrial complex to the more distant and less politically sensitive or powerful areas, without necessarily mitigating the potential environmental damages (Kobori 2017).

In prewar Japan rural industrialization remained important, especially in labourintensive industries, while agriculture provided industry with labour force, purchasing power and food and raw materials. Traditional considerations for industrial locations included local employment with relatively low wages (e.g. female byemployment in the peasant household economy), and supply of water, food and energy (both biomass and electricity). All of these functions had to be reorganized under the post-war national land development policy.

Unlike the 'global supply chain', which in this context essentially consists of a network of factories (plus perhaps headquarters) scattered in various parts of Asia, 
the key feature here is what might be called the 'resource nexus', the creation of an international competitive spatial cluster designed for combining specific sets of resources. In particular, local and domestic resources was to be efficiently combined with import resources. As industrialization proceeded, the resource nexus began to reorganize the entire spatial allocation of human and natural resources of the country. It encouraged the growth of cities, which provided resource-intensive industries with labour and the market (e.g. for electricity). A large proportion of population moved to cities, while a large part of rural areas became 'urban' at the same time. A new relationship between the city and the countryside was formed, with the premise that industries would have access to global resources to lead economic growth.

Other East Asian countries also adopted the seafront industrial complex strategy. In South Korea initial conditions for heavy and chemical industries were low, because most of the colonial legacy was located in the North. In 1973 the developmental state declared the programme for 'heavy and chemical industrialization', and a series of seafront complex were established at far south. They were distinctly separate from the traditional light industry zones. The new nexus included shipbuilding, automobile, steel and military-related machinery industries. In addition to the steel industry, which grew out of domestic demand and joined this development, petrochemical and shipbuilding industries were especially successful in exports. Meanwhile, in Seoul and its neighbouring regions and some other clusters, labour-intensive industries were transformed into the 'new' ones driven by the microelectronics revolution (Hashiya 1995, 43-46, 49-53; Ishizaki 1996, 65-86).

In Taiwan where traditionally fragmented small and medium-sized businesses were scattered across the island, the government-led strategy for heavy and chemical industrialization lasted for a relatively short period, from the late 1960s to the early 1970s. Even so, steel, petrochemical and shipbuilding industries were established, and they played a supporting role for the growth of labour-intensive and high-technology industries (Wade 1990, 86-112; Hashiya 1995, 46-49; Sato 1996, 96-101).

In China, the initial phase after the policy reform of 1979 saw a slow and difficult process of transition. Many heavy industries were located inland for political and strategic reasons and with the ideology that they should be developed close to where coal and other resources were found. Experts had to be persuaded that imports of resources were essential for further industrialization. The Pearl River delta, on the strength of the rich historical tradition of Hong Kong as a major trading hub and the export-zone initiatives in Canton in the 1970s, led the development of electronics industries, while the city of Shanghai (and the Yangtze River delta) initially suffered from the need to reorganize state-owned enterprises, heavy industries and coal mines, to cope with international competition. The establishment of Shanghai Baoshan Ironworks with the introduction of foreign (Japanese) technology and management was a turning point in China's commitment to the seafront development model. By the 1990s the Yangtze River delta reestablished itself as the main industrial complex with large imports of resources from abroad (Zhou 2007, 81-84, 119-121).

Here the linkage between the 'new' electronics-related industries and resourceintensive industries took a different form. Three 'megalopolis', a chain of connected 
metropolitan areas, located in Pearl River delta, Yangtze River delta and the national capital region (Beijing-Tianjin-Hebei) respectively, embraced megacity (or cities), the smaller cities and rural areas with township enterprises, and grew into a center of progressively larger urban networks. While heavy and chemical industries, especially steel and petrochemical sectors, were concentrated on the seafront to maximize the benefits from the economies of scale and access to imports, electronics and machinery industries were located across a variety of cities and countryside, so that the region could create intra-industry linkages and links to a large consumer market (Zhou 2007, 72-128). This was a more embracing model for combining the strength of natural and human resources than the earlier experiments in Japan and elsewhere, with accompanying, often more serious, problems such as air pollution. It also had equally powerful political and social consequences on the inequality and uneven resource allocation with other parts of China.

\subsection{Dealing with Local Resource Constraints}

In this section I wish to discuss the assumptions implicitly made for the discussion on intra-regional trade and industrialization by introducing the importance of nontradable resources, and the extent to which they affect the developmental state and the long-term path of economic development.

Up to around 1800, population growth did not cause major problems of environmental sustainability, in that nature was governed by forces of the geosphere (in which energy and material flows are determined by natural processes) or the biosphere (in which the eco-system and food chains function by incorporating human interventions rather than vice versa). Humans depended for their food on their own labour on arable land, and Malthusian or Boserupean dynamics were at work. Meanwhile, they depended for their energy on (mainly forest-derived) biomass, as well as on human and animal muscles, water and wind. Burning biomass was the basic technology for heating and lighting, as well as for clearing the land. But energy consumption per capita increased very slowly, while population growth was yet to reach the point of exhausting the land frontier in most parts of the world.

In the age of fossil-fuel-based industrialization and growth of world trade, local constraints were broken. Instead, securing raw materials from abroad became important, in order to extend the industrial capacity of the nation beyond the framework set by local resource constraints. Britain and Japan would not have been able to industrialize in the way they did, without imports of raw materials such as raw cotton and food. In the post-war period of economic growth in Asia, the regime of free trade became a vital element in overcoming the local resource constraints for the same reason, especially for relatively small economies, including many emerging ones.

At the same time, while food and fossil fuels could be imported relatively easily if the country earns foreign change through exports, the resulting growth put less tradable factors of production under unprecedented pressure. The most obvious such resources include water for agricultural use and local biomass energy. 
In fact, securing all essential resources for production and livelihood has been a twin target for the welfare of the local society for most of human history. If large parts of Asia, especially China and India, held an unusually large population in 1820, and exhibited a rapid expansion in absolute numbers during the last half century, it implies that these societies found answers to meet this target, especially in the early modern and the most recent periods.

Historians of the colonial period have discussed the more stagnant trends dividing these two periods, by relating famines, epidemics, disasters and wars to colonialism and/or the failure to secure resources for the local population. Economic and social historians have discussed the prevalence of poverty, social inequality and instability in the last two centuries, often by linking them to the resource shortage, especially that of land. Malthusian and neo-Malthusian thinkers have considered these issues in the context of population control. They have left unanswered the question of why population nevertheless grew so much in the long run.

The best-known approach to this question is to discuss the environmental characteristics of monsoon Asia. In describing post-war economic development up to c. 1980, Harry Oshima stressed the common socio-environmental characteristics of monsoon Asia, stretching from East and Southeast Asia to South Asia, in terms of seasonal rainfall patterns induced by monsoon winds, and the centrality of the large delta for the growth of rice farming and dense population. His formulation stresses the sequence of intensive rice farming, population growth, availability of cheap labour and labour-intensive industrialization leading to economic growth (Oshima 1987). This sequence has been further studied, especially with reference to East Asia. The development of intensive farming implied the availability of water and manure required for commercial crop production (Elvin and Ts'ui-jung 1998); Population growth required the maintenance of social order (Wong 1997); Labourintensive industrialization implied the capacity to trade primary products or labourintensive manufactured goods for capital-intensive and high-technology goods (Sugihara 2013b). On South Asia, difficulties of securing water delayed the rise of agricultural (land) productivity, which was eventually responded to by the green revolution and the introduction of tube wells (Roy 2006, 2007). This innovation made it possible for farmers to grow water-intensive, as well as labour- and land-intensive crops, and to provide the basis for full-fledged industrialization. The issue is how this sequence occurred in some parts of Asia to create a path and at what speed, while it did not in the other parts (or in comparably developed parts of Africa).

I suggest that, as far as monsoon Asia is concerned, three natural resource endowments, land, water and energy, have been important for both livelihood security and resource security. The usual factor endowment perspective singles out land and discusses its relationships with labour and capital. If land is scarce relative to labour, labour absorption is likely to be encouraged, and labour-intensive technology and labour-absorbing institutions are likely to develop. If land is abundant, such a path is less likely to be followed. Such a perspective ignores the crucial importance of water and (biomass) energy as local resource endowments. Major constraints to land use could be water or prevalence of infectious diseases, as a result of which people would not work on the land or raise the cattle. Seasonal and annual variability of 
water supply could be crucial for the stability of agriculture. Nearby forests or the 'waste land' from which timber, twigs or crop residues had been obtained, could disappear, as a result of population increase and expansion of arable land, and this could make it difficult for the peasant household to secure biomass energy for cooking, lighting and heating, and for the local economy to secure biomass resources for fuels and building materials (Sugihara 2012: 176-179). In other words, there was a great deal of environmental diversity, which worked for sustaining a large population in monsoon Asia since the early modern period, but, as industrialization occurred and tradable resources were brought in, some areas such as the Pacific coast or port cities and their environs along the Indian Ocean prospered, while hinterlands, semi-arid regions and mountainous areas took longer to meet the increased demand for local resources.

In many parts of contemporary China, water became scarce, and emerged as focal point of local, national and regional politics (Pomeranz 2009). The problem was aggravated by the need for dam construction for electricity generation. In contemporary India, a rapid progress in the use of tube well solved the issue of self-sufficiency of food and raised agricultural productivity, but resulted in the lowering of water tables. Free electricity for tube well users also distorts resource allocation, for example by making the improvement of electricity supply more difficult than otherwise (Shar 2009). Where electricity is not always available, securing local biomass energy for cooking and heating purposes could still be a matter of life and death. Vast number of hours was spent for water and fuel wood collection, mainly by women (Sugihara 2017).

Thus we consider a stable mix of land, water and energy as a resource security measure, and what might be called the 'water-food-energy nexus' as a livelihood security measure. The two measures are related to each other in a number of ways. The stable mix would provide a necessary, if not sufficient, condition for the livelihood nexus. In turn, the higher the livelihood security, the better the quality of labour and the quality of care would become. Under globalization the international competitiveness of the local society depends increasingly on these factors, rather than on abundant and disposable cheap labour. The combined strength of livelihood security and resource security would underscore the capacity of the developmental state. Its lack would imply the less favourable outcome.

\subsection{Concluding Remarks}

Components of regional integration discussed above were mainly economic. Compared to politically charged integration in Europe, Asia's regional integration was more strongly driven by trade and other economic factors. Part of the role of the state was carried out by commercial networks and by the local community. Even so, Asian states played a central role in regional integration by becoming the 'developmental state', that is by embracing 'developmentalism', in which economic development is a main policy goal. This was mostly clearly expressed in its effort to establish physi- 
cal infrastructure to access global resources. Elsewhere I have argued that the Asian norm has become 'developmentalism of free trade', that is, 'free trade if possible, state intervention if necessary' [Sugihara (2013a): for 'imperialism of free trade', see Gallagher and Robinson (1953)].

This ideology was a natural outcome of the Asian development path, which was built on the rich experience of the exploitation of socio-environmental characteristics of Monsoon Asia. At the same time, developmentalism must be sustainable both economically and environmentally, and at national, regional and global levels. Because Asia's growth rates remain comparatively high, the region has become a 'hot spot' of environmental problems. Moreover, by importing vast amounts of resources from outside the region, Asia is putting pressure on global environmental sustainability. Nevertheless, its capacity to generate intra-regional trade and the dynamics of technology and managerial transfer remains the best hope for sustainable economic development on a global scale. Politicians and bureaucrats should acknowledge the historical depth of the Asian path, and take advantage of it.

\section{References}

Akamatsu, K. (1962). A historical pattern of economic growth in developing countries. Developing Economies, Preliminary Issue, 1, 3-25.

Amjad, R. (1981). The development of labour intensive industries in ASEAN countries: An overview. In Amjad (Ed.), The development of labour intensive industries in ASEAN countries (pp. 1-28). Geneva: ILO.

Amjad, R. (1987). Human resource development: The Asian experience in employment and manpower planning: An overview. In Amjad (Ed.), Human resource planning: The Asian experience (pp. 1-37). Geneva: ILO.

Arpan, J. S., Barry, M., \& Van Tho, T. (1984). The textile complex in the Asia-Pacific region: The patterns and textures of competition and the shape of things to come. Research in International Business and Finance, 4(B), 101-164.

Baker, C., \& Phongpaichit, P. (2017). A history of Ayutthaya: Siam in the early modern world. Cambridge: Cambridge University Press.

Chaudhuri, K. N. (1990). Asia before Europe: Economy and civilisation in the Indian Ocean from the Rise of Islam to 1750. Cambridge: Cambridge University Press.

Elvin, M., \& Ts'ui-jung, L. (1998). Sediments of time: Environment and society in Chinese history. Cambridge: Cambridge University Press.

Gallagher, J., \& Robinson, R. (1953). Imperialism of free trade. Economic History Review, 6-1, $1-15$.

Hao, P. (2015). Kinsei Nisshin Tsusho Kankeishi [A history of Sino-Japanese trade relations in the early modern period]. Tokyo: Tokyo Daigaku Shuppankai.

Hashiya, H. (1995). Kankoku, Taiwan no NIEs-ka to Toshika [Development of newly industrializing economies and urbanization in South Korea and taiwan]. In R. Kojima \& N. Hataya (Eds.), Hatten Tojokoku no Toshika to Hinkonso [Urbanization and the poor in developing countries] (pp. 41-68). Tokyo: Ajia Keizai Kenkyusho.

Ishizaki, N. (1996). Kankoku no Jukagaku Kogyo Seisaku: Kaishi no Naigai Joken to Jisshi Shutai [South Korea's policy for heavy and chemical industries: Internal and external conditions for its establishment and actors for implementation]. In T. Hattori \& Y. Sato (Eds.), Kankoku, Taiwan no Hatten Mekanizumu [Patterns of development of South Korea and Taiwan] (pp. 65-86). Tokyo: Ajia Keizai Kenkyusho. 
Iwai, S. (2010). Choko to Goshi (Chaogong and Hushi). In H. Wada et al. (Eds.), Higashi Ajia Kingendai Tsushi 1 Higashi Ajia Sekai no Kindai: 19 Seiki [Modern and contemporary history of East Asia, Vol. 1, The modern period of the East Asian World: The 19th Century, pp. 134-153]. Tokyo: Iwanami Shoten.

Iwai, S. (2012). International society after "The transformation from Civilized to Barbarian”. (J. A. Fogel Trans.), Sino-Japanese Studies, 19(1), 1-22.

Kobori, S. (2010). Nihon no Enerugi Kakumei: Shigen Shokoku no Kingendai [The energy revolution in Japan: The modern and contemporary history of a resource-poor country]. Nagoya: Nagoya Daigaku Shuppankai.

Kobori, S. (2017). Rinkai Kaihatsu, Kogai Taisaku, Shizen Hogo: Kodo Seicho-ki Yokohama no Kankyoshi [Seafront development, anti-pollution policy and nature conservation: An environmental history of Yokohama in the period of high-speed growth]. In S. Shoji (Ed.), Sengo Nihon no Kaihatsu to Minshushugi: Chiiki ni Miru Sokoku [Development and democracy in post-war Japan: Conflicts at local settings] (pp. 71-104). Kyoto: Showado.

Lee, E. (1979). Egalitarian peasant farming and rural development: The case of South Korea. World Development, 7(4/5), 493-517.

Lewis, W. A. (1952). World production, prices, and trade, 1870-1960. Manchester School, 20(2), 105-138.

Lewis, W. A. (1954). Economic development with unlimited supplies of labour. Manchester School, 22(2), 139-191.

Lewis, W. A. (1978). Growth and fluctuations, 1870-1913. London: George Allen and Unwin.

Li, B. (1998). Agricultural development in Jiangnan, 1620-1850. Basingstoke: Macmillan.

Lieberman, V. (2003). Strange parallels: Southeast Asia in global context, c. 800-1830, Vol. 1 Integration on the Mainland. Cambridge: Cambridge University Press.

Lindert, P. H. (2003). Voice and growth: Was Churchill right? Journal of Economic History, 63(2), 315-350.

Lindert, P. H. (2004). Growing public: Social spending and economic growth, The Story (Vol. 1). Cambridge: Cambridge University Press.

Oshima, H. (1987). Economic development in Monsoon Asia: A comparative study. Tokyo: University of Tokyo Press.

Pomeranz, K. (2000). The great divergence: China, Europe, and the making of the modern world economy. Princeton: Princeton University Press.

Pomeranz, K. (2009). The Great Himalayan Watershed: Agrarian crisis, mega-dams and the environment. New Left Review, 58, 5-39.

Reid, A. (1993). Expansion and crisis: Southeast Asia in the age of commerce 1450-1680. New Haven: Yale University Press.

Riello, G., \& Roy, T. (Eds.), with the collaboration of Prakash, O., \& Sugihara, K. (2009). How India clothed the world: The world of South Asian textiles, 1500-1850. Leiden: Brill.

Roy, T. (2006). Roots of Agrarian Crisis in Interwar India: Retrieving a Narrative. Economic and Political Weekly, December 30, pp. 5389-5400.

Roy, T. (2007). A delayed revolution: Environment and Agrarian change in India. Oxford Review of Economic Policy, 23(2), 239-250.

Sato, H. (1996). Taiwan no Keizai Hatten ni okeru Seifu to Minkan Kigyo: Sangyo no Sentaku to Seika [Government and private enterprises in the economic development of Taiwan: Choice of industries and their performance]. In T. Hattori \& Y. Sato (Eds.), Kankoku, Taiwan no Hatten Mekanizumu [Patterns of development of South Korea and Taiwan] (pp. 87-118). Tokyo: Ajia Keizai Kenkyusho.

Sawai, M. (2012). Kindai Nihon no Kenkyu Kanhatsu Taisei [Modern Japan's system of technological research and development]. Nagoya: Nagoya Daigaku Shuppankai.

Scott, J. C. (2009). The art of not being governed: An Anarchist history of Upland Southeast Asia. New Haven: Yale University Press.

Seki, H. Nihon no Kogyo Seisan no Sakan na Chiiki [Main districts of industrial production in Japan]. http://hiroseki.sakura.ne.jp/industry.html, Accessed 9 August 2018. 
Shar, T. (2009). Taming the Anarchy: Groundwater governance in South Asia. Washington DC: Resource for the Future Press.

Singh, A. (1979). The "basic needs" approach to development vs the new international economic order: The significance of third world industrialization. World Development, 7(6), 585-606.

Sugihara, K. (1994). The development of an informational infrastructure in Meiji Japan. In L. Bud-Frierman (Ed.), Information Acumen: The understanding and use of knowledge in modern business (pp. 75-97). London: Routledge.

Sugihara, K. (1996). Ajiakan Boeki no Keisei to Kozo [Patterns and development of intra-Asian Trade]. Kyoto: Mineruva Shobo.

Sugihara, K. (Ed.). (2005). Japan, China and the growth of the Asian international economy, 1850-1949. Oxford: Oxford University Press.

Sugihara, K. (2012). "Kaseki-shigen Sekai Keizai" no Koryu to Baiomasu Shakai no Saihen [The emergence of a 'Fossil-fuel-driven world economy' and the reorganization of the biomass society]. In K. Sugihara, K. Wakimura, K. Fujita, \& A. Tanabe (Eds.), Rekishi no nakano Nettai Seizonken: Ontai Paradaimu o Koete [The tropical humanosphere in global history: beyond the temperate zone paradigm] (pp. 164-179). Kyoto: Kyoto Daigaku Shuppankai.

Sugihara, K. (2013a). 'Sengo Aji ni okeru Kogyoka-gata Kokusai Chitsujo no Keisei [The emergence of an industrialization-driven international order in post-war Asia]. In S. Akita (Ed.), Ajia kara Mita Gurobaru Hisutori: 'Choki no 18-seiki' kara 'Higashi-ajia no Keizaiteki Saiko' e (pp. 283-307). Kyoto: Mineruva Shobo.

Sugihara, K. (2013b). Labour-intensive Industrialization in global history: An interpretation of East Asian experiences. In G. Austin \& K. Sugihara (Eds.), Labour-intensive industrialization in global history (pp. 20-64). London: Routledge.

Sugihara, K. (2015). Asia in the growth of world trade: A Re-interpretation of the "Long Nineteenth Century". In U. Bosma, \& A. Webster (Eds.), Commodities, ports and Asian Maritime Trade $c$. 1750-1950 (pp. 17-58). Basingstoke: Palgrave Macmillan.

Sugihara, K. (2017). Monsoon Asia, intra-regional trade and fossil-fuel-driven industrialization. In G. Austin (Ed.), Economic development and environmental history in the Anthropocene: Perspectives on Asia and Africa (pp. 119-144). London: Bloomsbury Academic.

Sugihara, K., \& Wong, R. B. (2015). Industrious revolutions in early modern world history, In J. H. Bentley, \& S. Subrahmanyam (Eds.), Cambridge world history, Vol. 7: The Construction of a Global World, (2), 283-309. Cambridge: Cambridge University Press.

Takanaka, K. (2000). Higashi-ajia Choki Keizai Tokei 9: Gaikoku Boeki to Keizai Hatten [Longterm economic statistics of East Asia, Vol. 9, foreign trade and economic development]. Tokyo: Keiso Shobo.

United Nations Development Programme (UNDP). (1996). Human development report 1996. New York: UNDP.

van Liemt, G. (1992). Introduction. In van Liemt (Ed.), Industry on the move: Causes and consequences of international relocation in the manufacturing industry. Geneva: ILO.

Wade, R. (1990). Governing the market: Economic theory and the role of government in East Asian industrialization. Princeton: Princeton University Press.

Will, P.-E., \& Wong, R. B. (1991). Nourish the people: The state civilian granary system in China, 1650-1850. Ann Arbor: University of Michigan.

Wong, R. B. (1997). China transformed: Historical change and the limits of European experience. Ithaca NY: Cornell University Press.

International Monetary Fund (IMF). (various years). Direction of trade statistics yearbook.

Yanagisawa, H. (Ed.). (2015). Community, commons and natural resource management in Asia. Singapore: NUS Press.

Zhou, M. (2007). Chugoku Keizairon: Kodo Seicho no Mekanizumu to Kadai [Essays on the Chinese economy: The mechanism of high-speed growth and its problems]. Tokyo: Nihon Keizai Hyoronsha. 
Open Access This chapter is licensed under the terms of the Creative Commons AttributionNonCommercial-NoDerivatives 4.0 International License (http://creativecommons.org/licenses/bync-nd/4.0/), which permits any noncommercial use, sharing, distribution and reproduction in any medium or format, as long as you give appropriate credit to the original author(s) and the source, provide a link to the Creative Commons license and indicate if you modified the licensed material. You do not have permission under this license to share adapted material derived from this chapter or parts of it.

The images or other third party material in this chapter are included in the chapter's Creative Commons license, unless indicated otherwise in a credit line to the material. If material is not included in the chapter's Creative Commons license and your intended use is not permitted by statutory regulation or exceeds the permitted use, you will need to obtain permission directly from the copyright holder.

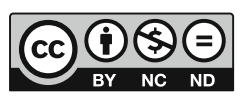

